\title{
PENGEMBANGAN PERANGKAT PEMBELAJARAN KOOPERATIF BERBASIS INFORMASI BERMAKNA MATERI PERSAMAAN DIFERENSIAL ORDE DUA UNTUK MELATIHKAN KOMPETENSI GURU PROFESIONAL
}

\author{
Fatriya Adamura $^{1)}$, Vera Dewi Susanti ${ }^{2)}$, Swasti Maharani ${ }^{3)}$ \\ ${ }^{1}$ Pendidikan Matematika, FPMIPA, IKIP PGRI Madiun \\ email: fat3ya_adamura@yahoo.co.id \\ ${ }^{2}$ Pendidikan Matematika, FPMIPA, IKIP PGRI Madiun \\ email: v_rad3wi@yahoo.co.id \\ ${ }^{3}$ Pendidikan Matematika, FPMIPA, IKIP PGRI Madiun \\ email: swastimaharani@yahoo.com
}

\begin{abstract}
Abstrak
Karena belum ada perangkat pembelajaran kooperatif berbasis informasi bermakna materi persamaan diferensial ordo dua, maka dilakukan penelitian pengembangan untuk mengembangkan perangkat pembelajaran kooperatif berbasis informasi bermakna materi persamaan diferensial ordo dua. Penelitian yang telah dilakukan adalah penelitian pengembangan. Penelitian dilakukan untuk mengembangkan perangkat pembelajaran kooperatif berbasis informasi bermakna materi persamaan diferensial ordo dua. Penelitian pengembangan dilakukan dengan menggunakan model 4-D yang telah dimodifikasi. Tahap model 4-D yang telah dimodifikasi terdiri dari pendefinisian (define), perancangan (design), dan pengembangan (develop). Kesimpulan yang didapatkan berdasarkan hasil penelitian adalah perangkat pembelajaran kooperatif berbasis informasi bermakna materi persamaan diferensial ordo dua yang baik telah didapatkan karena tim validator (ahli atau praktisi) menyatakan bahwa perangkat pembelajaran yang dikembangkan valid (berdasarkan pada rasional teoritik yang kuat dan terdapat konsistensi di antara komponenkomponen perangkat), dan dalam pelaksanaan uji coba, perangkat memenuhi syarat-syarat tertentu, yaitu: kemampuan dosen dalam mengelola pembelajaran baik, aktivitas mahasiswa selama pembelajaran sesuai dengan batas toleransi waktu ideal, mahasiswa memberi respon positif terhadap komponen-komponen perangkat pembelajaran, dan tes hasil belajar reliabel, valid dan sensitif, serta kemampuan mahasiswa dalam melaksanakan kompetensi guru profesional baik. Perangkat pembelajaran kooperatif berbasis informasi bermakna materi persamaan diferensial ordo dua yang dikembangkan: Satuan Acara Perkuliahan, Lembar Kegiatan Mahasiswa, dan Tes Hasil Belajar.
\end{abstract}

Kata kunci : Pengembangan Perangkat Pembelajaran, Pembelajaran Kooperatif, Informasi Bermakna, Materi Persamaan Diferensial Orde Dua, Kompetensi Guru Profesional

\section{PENDAHULUAN}

Pembelajaran matematika yang dirumuskan oleh National Council of Teachers

of Mathematics (dalam Yaniawati, 2008) menggariskan bahwa mahasiswa harus memelajari matematika melalui pemahaman dan aktif membangun pengetahuan baru dari pengalaman dan pengetahuan yang dimiliki sebelumnya. Untuk mewujudkan hal itu, Yaniawati (2008) merumuskan lima tujuan umum pembelajaran matematika, yaitu: "pertama, belajar untuk berkomunikasi (mathematical communication); kedua, belajar 
untuk bernalar (mathematical reasoning); ketiga, belajar untuk memecahkan masalah (mathematical problem solving); keempat, belajar untuk mengaitkan ide (mathematical connections); dan kelima, pembentukan sikap positif terhadap matematika (positive attitudes toward mathematics). Semua tujuan itu lazim disebut mathematical power (daya matematika)".

Mata kuliah persamaan diferensial merupakan salah satu mata kuliah yang dipelajari di Program Studi Pendidikan Matematika pada jenjang perguruan tinggi. Persamaan diferensial diperoleh berdasarkan pemodelan permasalahan yang ada di lingkungan masyarakat. Persamaan diferensial banyak muncul sebagai persamaan yang sangat penting dalam matematika terapan, karena banyak hukum dan hubungan fisis secara matematis muncul dalam bentuk persamaan ini. Sebagai contoh, dalam fisika, persamaan diferensial dari hukum Newton II timbul karena gejala alam, yang menerangkan bahwa massa kali percepatan dari suatu benda sama dengan gaya luar yang bekerja pada benda tersebut. Jika diasumsikan bahwa benda bermassa $\mathrm{m}$ yang bergerak sepanjang sumbu y dari sistem koordinat kartesius, maka ekspresi matematika dari hukum Newton II adalah persamaan diferensial: $m \frac{\mathrm{d}^{2} \mathrm{y}}{\mathrm{dt}^{2}}=\mathrm{F}$, dengan $\mathrm{F}$ melambangkan gaya luar yang bekerja pada benda. Persamaan ini merupakan persamaan diferensial karena memuat turunan kedua dari fungsi yang tidak diketahui $y(t)$. Selain diaplikasikan pada hukum Newton II, turunan kedua dari suatu fungsi yang tidak diketahui juga banyak diaplikasikan pada rumusan matematis dan fisis yang lain. Hal ini menunjukkan bahwa materi persamaan diferensial yang memuat turunan kedua (persamaan diferensial ordo dua) penting.

Mengingat pentingnya materi persamaan diferensial ordo dua, maka setiap mahasiswa yang sedang mempelajari materi persamaan diferensial harus dapat memahami dan menerapkan materi tersebut dalam situasi baru. Akan tetapi, terdapat masalah yang dialami penulis ketika membelajarkan materi persamaan diferensial ordo dua pada mahasiswa. Masalah yang dialami penulis adalah sebagian besar mahasiswa yang sedang belajar materi persamaan diferensial ordo dua belum mencapai ketuntasan belajar. Setelah dilakukan wawancara singkat dengan mahasiswa tersebut, didapatkan fakta bahwa mahasiswa merasa sulit memahami dan menerapkan materi persamaan diferensial ordo dua dalam situasi baru karena mahasiswa belum bisa memahami materi persamaan diferensial ordo dua secara mendalam.

Salah satu cara yang bisa dipakai untuk mengatasi masalah yang telah diuraikan di atas adalah dengan menjadikan materi persamaan diferensial ordo dua sebagai informasi yang bemakna. Ada dua hal yang membuat informasi menjadi bermakna, yaitu belajar bermakna dan teori skema (Nursalim, 2007). Berdasarkan uraian di atas, penulis bermaksud untuk melaksanakan pembelajaran yang mendorong mahasiswa untuk mampu mengubah materi persamaan diferensial linear ordo dua menjadi suatu informasi yang bermakna sehingga dapat membantu 
mahasiswa untuk memahami dan menerapkan materi tersebut ke dalam situasi baru.

Mata kuliah persamaan diferensial dipelajari oleh mahasiswa semester empat Program Studi Pendidikan Matematika pada semester genap. Pada semester yang sama, mahasiswa semester enam Program Studi Pendidikan Matematika juga memelajari mata kuliah Pengajaran Mikro. Mata kuliah Pengajaran Mikro merupakan mata kuliah prasyarat untuk mata kuliah Praktik Pengalaman Lapangan (PPL) yang dipelajari pada semester selanjutnya. Pada mata kuliah Pengajaran Mikro, setiap mahasiswa harus merencanakan dan memraktekkan pengajaran mikro sebanyak beberapa kali.

Dalam setiap kali praktek pengajaran mikro, diharapkan mahasiswa mendapatkan nilai minimal B. Hal yang diharapkan penulis tersebut bertentangan dengan fakta yang dihadapi penulis ketika mengampu mata kuliah Pengajaran Mikro. Fakta yang dialami penulis menunjukkan bahwa sebagian besar mahasiswa yang sedang belajar mata kuliah Pengajaran Mikro masih mendapatkan nilai di bawah B pada sebagian besar praktek yang dilaksanakan. Fakta yang tidak sesuai dengan harapan tersebut mendorong penulis untuk mencari penyebab dan alternatif solusi dari masalah tersebut. Berdasarkan analisa penulis, banyaknya mahasiswa yang mendapat nilai praktek pengajaran mikro di bawah nilai B karena mahasiswa belum menguasai empat kompetensi yang harus dimiliki oleh seorang guru profesional. Salah satu alternatif solusi yang bisa dilakukan adalah melatihkan kompetensi guru profesional pada setiap mata kuliah yang sedang dipelajari oleh mahasiswa. Pembelajaran yang memfasilitasi mahasiswa untuk mengubah materi persamaan diferensial ordo dua menjadi suatu informasi yang bermakna dan berlatih melaksanakan kompetensi guru profesional merupakan pembelajaran kooperatif berbasis informasi bermakna. Pembelajaran kooperatif berbasis informasi bermakna yang dimaksud adalah pembelajaran dengan menggunakan model kooperatif dan Lembar Kegiatan Mahasiswa (LKM) berbasis informasi bermakna. Karena selama ini belum ada perangkat pembelajaran kooperatif berbasis informasi bermakna materi persamaan diferensial ordo dua pada mata kuliah persamaan diferensial, maka penulis bermaksud untuk mengembangkan perangkat pembelajaran kooperatif berbasis informasi bermakna materi persamaan diferensial ordo dua pada mata kuliah persamaan diferensial untuk melatihkan kompetensi guru profesional.

\section{METODE PENELITIAN}

Rancangan penelitian pengembangan berbentuk One Group Pretest-Posttest Design. Subyek penelitian pengembangan perangkat pembelajaran kooperatif berbasis informasi bermakna adalah mahasiswa Prodi Pendidikan Matematika semester genap tahun akademik 2013/2014 IKIP PGRI Madiun kelas 4A. Model pengembangan perangkat pembelajaran pada penelitian ini adalah model Thiagarajan, Semmel, dan Semmel yang dikenal dengan four-D model (model 4D) (Adamura, 2011). Pada penelitian ini, 
model 4-D hanya dilaksanakan sampai tahap ketiga, yaitu pendefinisian (define), perancangan (design), dan pengembangan (develop). Beberapa hal yang telah dilakukan pada tahap pendefinisian adalah analisis awal akhir, analisis mahasiswa, analisis materi, analisis tugas, dan spesifikasi indikator pencapaian hasil belajar. Beberapa hal yang dilakukan pada tahap perancangan adalah pemilihan format, pemilihan media, perancangan awal perangkat pembelajaran, dan perancangan awal instrumen penelitian. Beberapa hal yang dilakukan pada tahap pengembangan adalah hasil validasi ahli, validasi keterbacaan, dan ujicoba perangkat.

Teknik pengumpulan data dilakukan dengan menggunakan lembar validasi, lembar validasi keterbacaan, lembar observasi (pengamatan) meliputi lembar pengamatan pengelolaan pembelajaran, lembar pengamatan aktivitas mahasiswa, lembar pengamatan kemampuan mahasiswa dalam melaksanakan empat kompetensi guru profesional, angket respon mahasiswa, dan tes hasil belajar. Analisis data meliputi perangkat pembelajaran dikatakan valid menurut para validator jika para validator memberikan penilaian minimal 3, kemampuan dosen dalam mengelola pembelajaran dikatakan baik jika rata-rata skor dari setiap aspek pada setiap pertemuan minimal 3, aktivitas mahasiswa dikatakan efektif jika sesuai dengan batasan waktu ideal dan toleransi keefektifan aktivitas mahasiswa, kemampuan mahasiswa dalam melaksanakan kompetensi guru profesional dikatakan baik jika nilai rata-rata kemampun mahasiswa dalam melaksanakan setiap kompetensi guru profesional yang diamati minimal 3, respon mahasiswa dikategorikan positif jika persentase respon positif mahasiswa minimal $80 \%$ untuk tiap aspek. Analisis butir soal meliputi sensitivitas butir, validitas butir, dan reliabilitas tes.

\section{HASIL DAN PEMBAHASAN}

Penelitian yang dilakukan adalah penelitian ujicoba. Penelitian ujicoba dilakukan pada penelitian pengembangan perangkat pembelajaran. Penelitian ujicoba dilakukan di kelas IV C Prodi Pendidikan Matematika FPMIPA IKIP PGRI Madiun semester genap tahun akademik 2013/2014. Model pengembangan perangkat pembelajaran pada penelitian ini adalah model Thiagarajan, Semmel, dan Semmel yang dikenal dengan four-D model (model 4-D). Pada penelitian ini, model 4-D hanya dilaksanakan sampai tahap ketiga, yaitu pendefinisian (define), perancangan (design), dan pengembangan (develop).

Beberapa hal yang telah dilakukan pada tahap pendefinisian adalah analisis awal akhir, analisis mahasiswa, analisis materi, analisis tugas, dan spesifikasi indikator pencapaian hasil belajar. Beberapa hal yang dilakukan pada tahap perancangan adalah pemilihan format, pemilihan media, perancangan awal perangkat pembelajaran yang meliputi Satuan Acara Perkuliahan (SAP), Lembar Kegiatan Mahasiswa (LKM), dan Tes Hasil Belajar, perancangan awal instrumen penelitian yang meliputi lembar validasi perangkat, lembar pengamatan aktivitas mahasiswa, lembar 
pengamatan pengelolaan pembelajaran, tes hasil belajar, dan lembar respon mahasiswa. Beberapa hal yang dilakukan pada tahap pengembangan adalah hasil validasi ahli, validasi keterbacaan, dan ujicoba perangkat.

Pada tahap validasi ahli, didapatkan perangkat pembelajaran yang meliputi Satuan Acara Perkuliahan (SAP), Lembar Kegiatan Mahasiswa (LKM), dan Tes Hasil Belajar yang telah divalidasi oleh ahli dan dapat digunakan dengan sedikit revisi. Pada validasi keterbacaan, dilakukan revisi terhadap Lembar Kegiatan Mahasiswa (LKM) dan Tes Hasil Belajar. Pada pelaksanaan ujicoba, didapat beberapa data yang telah dianalisis. Beberapa data yang diperoleh pada saat pelaksanaan ujicoba perangkat pembelajaran meliputi: nilai pretest, data aktivitas mahasiswa selama pembelajaran, kemampuan dosen dalam mengelola pembelajaran, nilai posttest, dan data respon mahasiswa.

Hasil analisis data ini menunjukkan bahwa rata-rata skor kemampuan dosen dalam mengelola pembelajaran untuk pertemuan 1, 2, dan 3 memiliki kriteria minimal baik. Berdasarkan hal tersebut, maka kemampuan dosen dalam mengelola pembelajaran memenuhi kriteria baik.

Pengamatan aktivitas mahasiswa dilakukan terhadap enam orang mahasiswa selama tiga kali pelaksanaan pembelajaran berturut-turut (3 SAP). Hasil pengamatan aktivitas mahasiswa menunjukkan bahwa setiap aktivitas mahasiswa untuk setiap pertemuan memenuhi kriteria batasan keefektifan. Hal ini berarti bahwa aktivitas mahasiswa dikatakan efektif. Kemampuan mahasiswa dalam melaksanakan kompetensi guru profesional dikatakan baik karena nilai rata-rata kemampun mahasiswa dalam melaksanakan setiap kompetensi guru profesional yang diamati pada tiga kali pertemuan minimal 3. Hasil angket respon mahasiswa pada penelitian ujicoba menunjukkan bahwa dapat dikatakan bahwa respon positif mahasiswa terhadap semua aspek pembelajaran di atas 85\%. Hal ini berarti bahwa setiap aspek direspon positif oleh mahasiswa.

Hasil analisis sensitivitas butir tes, validitas butir tes, dan reliabilitas tes adalah sebagai berikut. Tabel 1 berikut ini menunjukkan sensitivitas setiap butir tes.

Tabel 1. Sensitivitas Setiap Butir Tes Hasil Belajar

\begin{tabular}{|c|c|c|}
\hline No soal & Sensitivitas & Interpretasi \\
\hline 1 & 0,60 & Peka \\
\hline 2 & 0,64 & Peka \\
\hline 3 & 0,57 & Peka \\
\hline
\end{tabular}

Tabel 1 menunjukkan bahwa setiap butir tes hasil belajar peka atau sentitif terhadap pembelajaran. Hal ini berarti bahwa semua butir tes dikatakan sensitif.

Berdasarkan rumus korelasi product moment, diperoleh validitas setiap butir tes sebagai berikut.

Tabel 2. Hasil Analisis Validitas Butir Tes

\begin{tabular}{|c|c|c|}
\hline No. Soal & $\mathbf{r}_{\mathbf{x y}}$ & Tingkat Validitas \\
\hline 1 & 0,74 & Tinggi \\
\hline 2 & 0,88 & Sangat Tinggi \\
\hline 3 & 0,77 & Tinggi \\
\hline Tabel 2 & \multicolumn{2}{|c|}{ menunjukkan bahwa tingkat }
\end{tabular}

validitas dari masing-masing butir tes berada pada kategori tinggi dan sangat tinggi. Hal ini 
berarti bahwa semua butir tes tersebut dapat dikatakan valid.

Berdasarkan perhitungan reliabilitas tes, maka diperoleh koefisien reliabilitas $\alpha=0,72$. Hal ini berarti bahwa reliabilitas instrumen tes hasil belajar yang dikembangkan termasuk dalam kategori tinggi. Hal ini berarti bahwa instrumen tes hasil belajar reliabel.

Berdasarkan hasil analisis sensitivitas butir tes, validitas butir tes, dan reliabilitas, maka dapat disimpulkan bahwa tes hasil belajar sensitif, valid, dan reliabel.

Perangkat pembelajaran kooperatif berbasis informasi bermakna materi persamaan diferensial orde dua pada mata kuliah Persamaan Diferensial Prodi Pendidikan Matematika FPMIPA IKIP PGRI Madiun Kelas IV C Prodi Pendidikan Matematika FPMIPA IKIP PGRI Madiun yang baik telah didapatkan dengan menggunakan model 4-D yang telah dimodifikasi. Hal ini karena aktivitas mahasiswa efektif, kemampuan dosen dalam mengelola pembelajaran baik, kemampuan mahasiswa dalam melaksanakan kompetensi guru profesional baik, tes hasil belajar sensitif, valid, dan reliabel, respon mahasiswa positif. Perangkat pembelajaran yang didapatkan meliputi Satuan Acara Perkuliahan (SAP), Lembar Kegiatan Mahasiswa (LKM), dan Tes Hasil Belajar (THB).

\section{KESIMPULAN DAN SARAN}

\section{Kesimpulan}

Kesimpulan yang didapatkan berdasarkan hasil penelitian adalah perangkat pembelajaran kooperatif berbasis informasi bermakna materi persamaan diferensial ordo dua dikembangkan dengan menggunakan model pengembangan 4D yang dimodifikasi. Pengembangan perangkat pembelajaran pada penelitian ini dilakukan sampai tahap ketiga, yaitu: pendefinisian (define), perancangan (design), dan pengembangan (develop). Perangkat pembelajaran kooperatif berbasis informasi bermakna materi persamaan diferensial ordo dua yang dikembangkan meliputi: (1) Satuan Acara Perkuliahan (SAP), (2) Lembar Kegiatan Mahasiswa (LKM), dan (3) Tes Hasil Belajar (THB).

\section{Saran}

Saran yang dikemukakan berdasarkan hasil penelitian adalah perangkat pembelajaran yang telah dikembangkan pada penelitian ini masih perlu diterapkan di kelas lain untuk melihat efektivitas perangkat pembelajaran ini.

\section{DAFTAR PUSTAKA}

Adamura, Fatriya. 2011. Pembelajaran Diskusi Kelas Berbasis Diskusi Kelompok Intuitif pada Mata Kuliah Sistem Geometri untuk Melatihkan Proses Berpikir Intuitif dan Kompetensi Guru Profesional. Penelitian Mandiri. IKIP PGRI Madiun

Nursalim, Mochamad dkk. 2007. Psikologi Pendidikan. Surabaya: Unesa University Press

Sagala, Syaiful. 2009. Kemampuan Profesional Guru dan Tenaga Kependidikan. Bandung: Alfabeta Yaniawati. 2008. Membuat Belajar Matematika menjadi Bergairah. (http://acehforum.com, diakses 23 September 2013) 